\title{
O meme político: Uma análise na perspectiva tecnológica e democrática
}

\author{
The political meme: An analysis from a technological and democratic perspective \\ El meme político: Un análisis desde una perspectiva tecnológica y democrática
}

Recebido: 07/06/2021 | Revisado: 07/10/2021 | Aceito: 07/13/2021 | Publicado: 24/07/2021

Kênia Isonilda Pinheiro e Eleutério

ORCID: https://orcid.org/0000-0002-2671-1367

Universidade Federal dos Vales do Jequitinhonha e Mucuri, Brasil

E-mail: kenia.eleuterio@ufvjm.edu.br

Simone Alves Martins

ORCID: https://orcid.org/0000-0003-1125-7277

Universidade Federal dos Vales do Jequitinhonha e Mucuri, Brasil

E-mail: draalvesmartins@gmail.com

João Paulo Calembo Batista Menezes

ORCID: https://orcid.org/0000-0002-4739-839X

Universidade Federal dos Vales do Jequitinhonha e Mucuri, Brasil

E-mail: joao.calembo@ufvjm.edu.br

Márcio Atchtschin Santos

ORCID: https://orcid.org/0000-0002-9436-4723

Universidade Federal dos Vales de Jequitinhonha e Mucuri, Brasil

E-mail: marcio.achtschin@ufvjm.edu.br

Marcio Coutinho de Souza

ORCID: https://orcid.org/0000-0002-4238-1572

Universidade Federal dos Vales do Jequitinhonha e Mucuri, Brasil

E-mail: marcio.souza@ufvjm.edu.br

Raquel Cristina Lucas Mota

ORCID: https://orcid.org/0000-0003-1543-4306

Universidade Federal dos Vales do Jequitinhonha e Mucuri, Brasil

E-mail: raquel.lucasmota@ufvjm.edu.br

\begin{abstract}
Resumo
$\mathrm{O}$ artigo tem o objetivo de analisar a linguagem memética no espaço virtual, em um contexto democrático e de representação da cultura política. A pesquisa é definida como qualitativa e exploratória, com técnica de coleta de dados bibliográfica. Os resultados apontam para a capacidade de comunicação e divulgação de ideias e opiniões dos memes, com potencial para suscitar transformações na opinião pública e influenciar disputas eleitorais, fortalecendo a sua representatividade democrática e de cultura política; mas também indicam a necessidade de se avaliar sua capacidade de interação e produção de sentido no cenário político, para que seja permitido ao cidadão um maior engajamento políticodemocrático.
\end{abstract}

Palavras-chave: Meme político; Cultura política; Representatividade; Tecnologia; Democracia.

\begin{abstract}
The article aims to analyze the memetic language in virtual space, in a democratic context and representation of political culture. The research is defined as qualitative and exploratory, with a bibliographic data collection technique. The results point to the memes' ability to communicate and disseminate ideas and opinions, with the potential to bring about changes in public opinion and influence electoral disputes, strengthening their democratic representation and political culture; but they also indicate the need to assess their ability to interact and produce meaning in the political scenario, so that the citizen is allowed greater political-democratic engagement.

Keywords: Political meme; Political culture; Representativeness; Technology; Democracy.

\section{Resumen}

El artículo tiene como objetivo analizar el lenguaje memético en el espacio virtual, en un contexto democrático y de representación de la cultura política. La investigación se define como cualitativa y exploratoria, con una técnica de recolección de datos bibliográficos. Los resultados apuntan a la capacidad de los memes para comunicar y difundir ideas y opiniones, con el potencial de generar cambios en la opinión pública e incidir en las disputas electorales, fortaleciendo su representación democrática y cultura política; pero también señalan la necesidad de evaluar su capacidad de interacción y
\end{abstract}


producción de sentido en el escenario político, para que la ciudadanía tenga un mayor compromiso político-democrático.

Palabras clave: Meme político; Cultura política; Representatividade; Tecnología; Democracia.

\section{Introdução}

Com a promulgação da Constituição da República Federativa do Brasil de 1988, os debates no contexto do papel do Estado e sua efetiva política para garantir as demandas da sociedade foram impulsionados, o que determinou um aprofundamento da democracia participativa em face das novas tecnologias digitais e sociais, consubstanciando no surgimento de uma nova faceta da democracia denominada democracia eletrônica ou democracia digital ou ciberdemocracia, definida por Castells (2003) como uma nova forma de conceber a democracia, com possibilidade de expressão popular em sua integralidade e por Lévy (2000) como uma verdadeira Ágora ${ }^{1}$ virtual que permite às pessoas cultivarem a inteligência coletiva e a vivência democrática.

Nessa sociedade interconectada os cidadãos passaram a vivenciar novas maneiras de construção, apropriação e compartilhamento de ideias e conhecimentos, trazendo a perspectiva de as novas tecnologias serem entendidas como instrumentos fundamentais para o desenvolvimento dentro de uma sociedade democrática. Nesse cenário, as mídias sociais garantiram espaço na vida dos cidadãos e a internet se destacou como novo formato de comunicação democrática, despontando como imprescindível no mover da política na atualidade, impondo à democracia digital novos parâmetros para lidar com as complexidades surgidas na relação entre as tecnologias e as práticas democráticas.

Assim, a comunicação política que antes era determinada por ferramentas clássicas, como propagandas televisivas, charges, jornais, passou a ser comandada por novas possibilidades de comunicação determinadas pelo marketing político, transformando o universo das campanhas eleitorais em um campo muito mais amplo e moderno para exposição de ideias e debates, permitindo aos partidos políticos segmentar perfis de usuários e promover a interação rápida e fácil com os eleitores (Duenas et al., 2019), ganhando destaque nesse novo espaço digital as redes sociais, como Facebook, Instagram, WhatsApp e Twitter, que passaram a ter grande influência nas campanhas eleitorais, trazendo reflexos para a vida política e social dos cidadãos (RodríguezAndrés, 2018).

Consubstanciado nesse novo cenário informacional nasce o meme político, uma linguagem midiática que pode ser traduzida em desenhos, sons, ideias, capacidades e valores estéticos ou morais, que toma conta das redes sociais e das campanhas eleitorais. Com conceito criado por Richard Dawkins em 1976, o meme é definido como uma unidade de evolução cultural que se autopropaga, evoluindo como forma comunicativa e de interação, passando a ser reconhecido como formador de opinião pública, tendo em vista sua proliferação rápida e de efeito considerável nos internautas (Shifman \& Chagas, 2020).

Tem-se, assim, que a relevância do trabalho está no destaque dado ao tema no cenário mundial digital e na importância do debate sobre o papel dos memes na sociedade democrática e informacional. Nessa perspectiva, o trabalho tem como ponto de partida a concepção de democracia relacionada à tecnologia, avançando para o papel de representatividade dos memes na cultura política, suscitando os seguintes questionamentos: Como são percebidos e analisados os memes políticos nas pesquisas acadêmicas? Como têm-se pautado as discussões sobre a linguagem memética na concepção de cultura política e de representatividade democrática?

$\mathrm{O}$ artigo tem o objetivo de analisar a linguagem memética no espaço virtual, em um contexto democrático e de representação da cultura política. Para atender a essa proposta, inicialmente busca-se tecer considerações acerca do avanço tecnológico e sua importância na sociedade democrática e informacional, para depois trazer a compreensão dos memes como instrumentos de cultura política e de interação democrática, e finalmente voltar-se ao estudo dos memes políticos nas pesquisas

\footnotetext{
${ }^{1}$ Praça pública das antigas cidades gregas, local onde ocorriam os debates políticos.
} 
Research, Society and Development, v. 10, n. 9, e19010917960, 2021

(CC BY 4.0) | ISSN 2525-3409 | DOI: http://dx.doi.org/10.33448/rsd-v10i9.17960

acadêmicas, expondo as discussões e os resultados da investigação.

O estudo está estruturado nas seguintes seções: Introdução, onde estão relacionados a relevância, problema e o objetivo da pesquisa; Metodologia; Referencial Teórico, que consta de três subseções: Sociedade democrática e sociedade da informação, Principais categorias taxonômicas de classificação dos memes, Os memes como instrumentos da cultura política e de interação democrática; Resultados e Discussões; Considerações Finais e Referências.

\section{Metodologia}

Trata-se de um estudo de revisão bibliográfica realizado de forma sistematizada e sua construção se baseia nas discussões sobre o tema em literatura científica nacional e internacional. Destarte, essa pesquisa é definida como qualitativa e exploratória, com técnica de coleta de dados bibliográfica. De acordo com Neves (1996), a abordagem qualitativa compreende um conjunto de técnicas de interpretação diversas, que busca obter dados descritivos através do contato interativo do pesquisador com seu objeto de estudo, com o objetivo de traduzir e expressar os sentidos do mundo social. Já a pesquisa exploratória, segundo Botelho \& Cruz (2013), tem o objetivo de examinar o conhecimento sobre o tema pesquisado sob outras perspectivas, promovendo a familiaridade com o assunto; o que nesse trabalho se dá na coleta de dados concretos, com definição, delineamento e planejamento, utilizando o levantamento elaborado a partir dos artigos científicos coletados (Prodanov \& Freitas, 2013).

A pesquisa bibliográfica, alinhada ao estudo exploratório, constitui o primeiro passo de um processo de pesquisa, qualquer que seja o problema a ser pesquisado, com a finalidade de obter conhecimento prévio do tema na literatura e analisar as principais teorias relacionadas a ele (Botelho \& Cruz, 2013), com a principal vantagem de permitir ao investigador a cobertura de uma gama de fenômenos muito mais ampla do que aquela que poderia ser pesquisada diretamente (Gil, 2002).

No que diz respeito aos procedimentos de coleta de dados bibliográficos, recorreu-se a estudos conceituados e recentes para embasar as reflexões sobre tecnologia e democracia, e a autores consagrados como Castells (1999, 2003) e Lévy (1999, 2000), que trazem a proposta de se repensar os caminhos da humanidade no contexto das tecnologias e da sociedade democrática. Utilizou-se de publicações em sites e plataformas virtuais para agregar informações e o conhecimento sobre a linguagem memética.

Para embasar as discussões e responder aos questionamentos levantados no artigo, as buscas sobre o assunto meme político foram realizadas em revistas científicas nos meses de abril a agosto de 2020, abrangendo artigos publicados no período entre janeiro de 2015 a janeiro de 2020. Observou-se no acervo selecionado que: no ano de 2020 foram seis publicações referentes ao assunto, seguido por três em 2019, duas em 2018, três em 2017 e uma publicação em 2016.

Foi realizada uma leitura reflexiva do material escolhido, examinando os resumos, introduções e conclusões ou considerações finais, que apontaram questões da problemática, objetivos centrais, metodologias e resultados fundamentais de cada trabalho, sendo averiguada as recentes abordagens feitas sobre a temática e os seus resultados, podendo assim, destacar 4 pontos relevantes acerca dos memes políticos no contexto de tecnologia e democracia, discutidos na seção 4.

\section{Referencial Teórico}

O referencial teórico está subdividido em três seções: a primeira apresenta um estudo sobre o avanço tecnológico e a sociedade da informação, com vistas a refletir sobre o papel das tecnologias no fortalecimento da democracia. Na seção dois são descritas as principais categorias taxonômicas de análises dos memes políticos, além de demonstrar como estes são classificados. 
Research, Society and Development, v. 10, n. 9, e19010917960, 2021

(CC BY 4.0) | ISSN 2525-3409 | DOI: http://dx.doi.org/10.33448/rsd-v10i9.17960

Na seção três é exposto como o meme político está inserido na cultura política e como é entendido no contexto de cibercultura, visto sob a perspectiva de comunicação política e democrática.

\subsection{Sociedade democrática e sociedade da informação}

O avanço tecnológico e a globalização da informação determinaram um novo panorama no cotidiano das pessoas, impulsionando o desenvolvimento de sociedades mais participativas e democráticas. Castells $(1999,2003)$ trata dessa nova era de informação e conhecimento como um momento histórico primordial da sociedade interconectada mundialmente, onde a base de todas as relações é estabelecida através da informação e da capacidade das pessoas de gerar e processar conhecimentos. É o que o autor chama de Sociedade em Rede.

Partindo desse mesmo entendimento, Lévy $(1999,2000)$ chama de Ciberespaço esse lugar de comunicação virtual que se dá pela interconexão global de computadores, que compreende um espaço com potencialidades de gerar novos modos de agir e de interação social, com um fluxo contínuo de ideias e ações práticas, que o autor chama de Cibercultura.

A partir dessa perspectiva foram repensadas as concepções desse novo espaço informacional, considerando a possibilidade das tecnologias, através da ciberdemocracia, romperem com os monopólios de poder dos meios de comunicação e viabilizarem a participação da população no sistema político de forma democrática (Pinho, 2012), com capacidade de induzir a abertura de novos espaços e canais de interação através da democracia participativa e deliberativa (Magrani, 2014). Tem-se esse mesmo entendimento em Silva et al. (2016), que veem na tecnologia uma ferramenta que abre caminhos para novas compreensões da democracia e um potencial canal de transformação e reconfiguração das vivências democráticas; Rocha et al. (2019) que ressaltam a transformação social e econômica ocorrida a partir da evolução tecnológica e da informatização na sociedade contemporânea e Barbosa et al. (2021), que se referem às informações e dados que trafegam no espaço cibernético como elementos essenciais para a autonomia e liberdade da sociedade da informação.

Nesse sentido, os autores evidenciam a importância das tecnologias no fortalecimento das práticas e estruturas democráticas, possibilitando a democracia no mundo virtual, mas enxergam os desafios e complexidades desse contexto, tanto na seara ética e no respeito aos direitos fundamentais, quanto na regulação de uso, na segurança e proteção de dados. E veem de forma negativa as consequências da informatização na sociedade atual e no mercado de trabalho, que trazem danos a grande parcela de trabalhadores, se referindo à necessidade de as informações trafegarem de forma segura no espaço cibernético e a importância da tecnologia ser utilizada como ferramenta para possibilitar a organização das atividades humanas e dos processos de reestruturação socioeconômica. Considerando, assim, para que tudo isso se torne real, a necessidade de um sistema político capaz de tornar legítimas e transparentes as ferramentas digitais de modo a permitir ao cidadão um maior engajamento político-democrático na esfera pública on-line (Pinho, 2012; Magrani, 2014; Silva et al., 2016; Rocha et al., 2019; Barbosa et al., 2021).

Um dos desafios vivenciados nesse cenário é o uso pelos cidadãos da informação enquanto instrumento de política, determinado a necessidade de se ponderar os limites da liberdade de expressão, considerando a influência negativa da desinformação e das notícias falsas sobre a vida as pessoas, com a propagação de discursos de ódio, discriminação e intolerância e o consequente risco à democracia virtual (Oliveira et al., 2019).

É nesse sentido que se entende o temor de Bucci (2019, p. 21) quando diz que "os relatos fraudulentos e notícias enganosas se tornaram um fator de desagregação das sociedades democráticas deste início de século XXI, e se vê a preocupação de Oliveira et al. (2019) ao destacarem a necessidade de se entender o papel essencial das tecnologias na comunicação e na livre manifestação e a urgência de um projeto político e cultural capaz de evitar que a ideologia das redes sucumba à especulação 
Research, Society and Development, v. 10, n. 9, e19010917960, 2021

(CC BY 4.0) | ISSN 2525-3409 | DOI: http://dx.doi.org/10.33448/rsd-v10i9.17960

econômica e à ilusão de que os homens e a sociedade podem mudar simplesmente pela magia do espaço virtual. Tudo isso se resume no entendimento de que não há regime democrático capaz de sobreviver quando não alimentado da verdade para se fortalecer e prosperar.

Diante disso é necessário ter em mente que, embora a Carta Magna de 1988 proteja a liberdade de expressão como direito fundamental e essencial à construção de uma sociedade livre, justa, solidária e sem preconceitos, o direito de exprimir deve respeitar e harmonizar com os princípios da dignidade humana e com os direitos e valores constitucionais e pautar-se pelo equilíbrio entre o pluralismo e o respeito às opiniões contrárias e às diferenças; e assim não sendo, considerar-se-á um exercício abusivo do direito à liberdade de expressão e afronta aos valores democráticos (Toffoli, 2019).

Tem-se, assim, que o direito de se exprimir livremente, por mais importante que seja, não é absoluto, sofrendo restrições legais, éticas e morais, não se albergando a invocação ao direito à liberdade de expressão para ofender aspectos relativos à credo, raça, gênero, opção política, condição social e econômica. Isso leva ao entendimento que, embora a tecnologia seja reconhecidamente uma ferramenta a serviço da democracia, o seu potencial democrático e emancipatório é relativizado quando não há uma cultura voltada para o entendimento e desenvolvimento da pessoa e sua participação na sociedade informacional como cidadão portador de direitos e obrigações.

Sob esse olhar é que se vislumbra os perigos do uso indiscriminado das mídias sociais no cenário político, considerando ainda outros entraves, tais como: a internet não é universalmente acessível a todos os cidadãos na realidade brasileira; há limitação ao valor da esfera pública virtual em termos de participação democrática, causando o risco de que os cidadãos que possuem acesso à internet sejam os mesmos que já possuem acesso ao debate público crítico-racional; o analfabetismo digital em grande escala no Brasil, o que significa excluir do debate aqueles que não possuem acesso às tecnologias, e, consequentemente, continuam sem voz na esfera pública. Outra situação percebida na realidade brasileira é o analfabetismo funcional digital onde muitos são excluídos digitalmente, e embora tenham o acesso às tecnologias, não têm o entendimento e o poder de apropriar-se de tudo que lhes é oferecido (Pinho, 2012; Magrani, 2014).

Considera-se justificáveis as inquietações percebidas nesse cenário diante das complexidades desse novo espaço informacional e da possibilidade de gerar distorções no funcionamento da democracia. Evidencia-se, assim, que ainda há um longo caminho para plenitude da ciberdemocracia; e nessa caminhada há a necessidade de se tomar consciência de que o mundo está à frente de uma realidade ainda inconclusa e em constante construção, tendo em vista que o desenvolvimento tecnológico, assim entendido por Cristóvam et al. (2020), é capaz de proporcionar condições revolucionárias e alteração de paradigmas, construindo novas relações que não podem ser desconsideradas em seus múltiplos âmbitos.

Essa perspectiva deve ser concretizada a partir da sociedade e das instituições democráticas, diante da real compreensão desse fenômeno e do engajamento na formulação de ferramentas e diretrizes adequadas para tratá-lo no seu contexto social, político, cultural e humano; com o pensamento voltado para a proposta de Castells (1999, 2003) e Lévy $(1999,2000)$ de repensar os caminhos da humanidade no contexto da tecnologia como instrumento para o desenvolvimento das potencialidades da sociedade, engajamento dos cidadãos na vida política e fortalecimento da democracia.

\subsection{Principais categorias taxonômicas de classificação dos memes}

A Teoria Memética é considerada uma ciência empírica que estuda a replicação, o espalhamento e a evolução dos memes, e seus estudos estendem-se no campo da comunicação política e da democracia virtual (Shifman \& Chagas, 2020), mas o conceito acabou sendo incorporado à linguagem da internet, e os memes tornaram-se conhecidos pelo cunho humorístico e ganharam as 
redes como fenômenos contemporâneos da comunicação política, com a função de construir e desconstruir a imagem de determinado candidato, desenvolvidos muitas vezes com imagens despretensiosas e sem muitos recursos tecnológicos (Trein, 2019).

Chagas et al. (2017) relacionam o humor como principal característica da linguagem dos memes, que em conexão com a política na internet, atribui novos significados a conteúdos típicos da cultura popular, que Popolin (2019) denomina de discussão pública, por trazerem humor de forma latente, com uma construção que se faz a partir de uma imagem estática, com características de fotomontagens e legendas sobrepostas. Usando os parâmetros desses dois autores, tem-se um exemplo de meme persuasivo nas Figuras 1 e 2, onde é possível observar o cunho humorístico presente nas imagens, evidenciando piadas envolvendo candidatos e situações políticas do cotidiano.

Figura 1 - Memes persuasivos com cunho humorístico baseado nos episódios do Chaves.

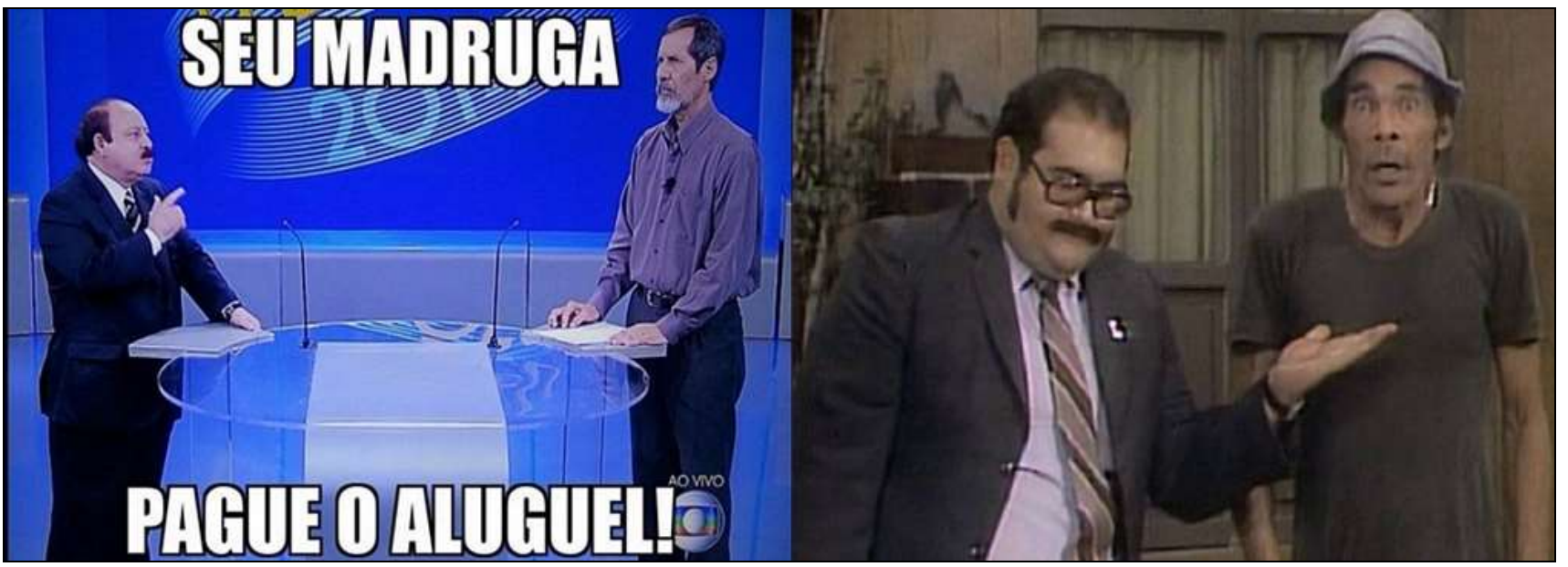

Fonte: G1 (2014)

Fonte: Hypeness (2017)

Figura 2 - Memes persuasivos com cunho humorístico baseado em fotomontagens e legendas sobrepostas

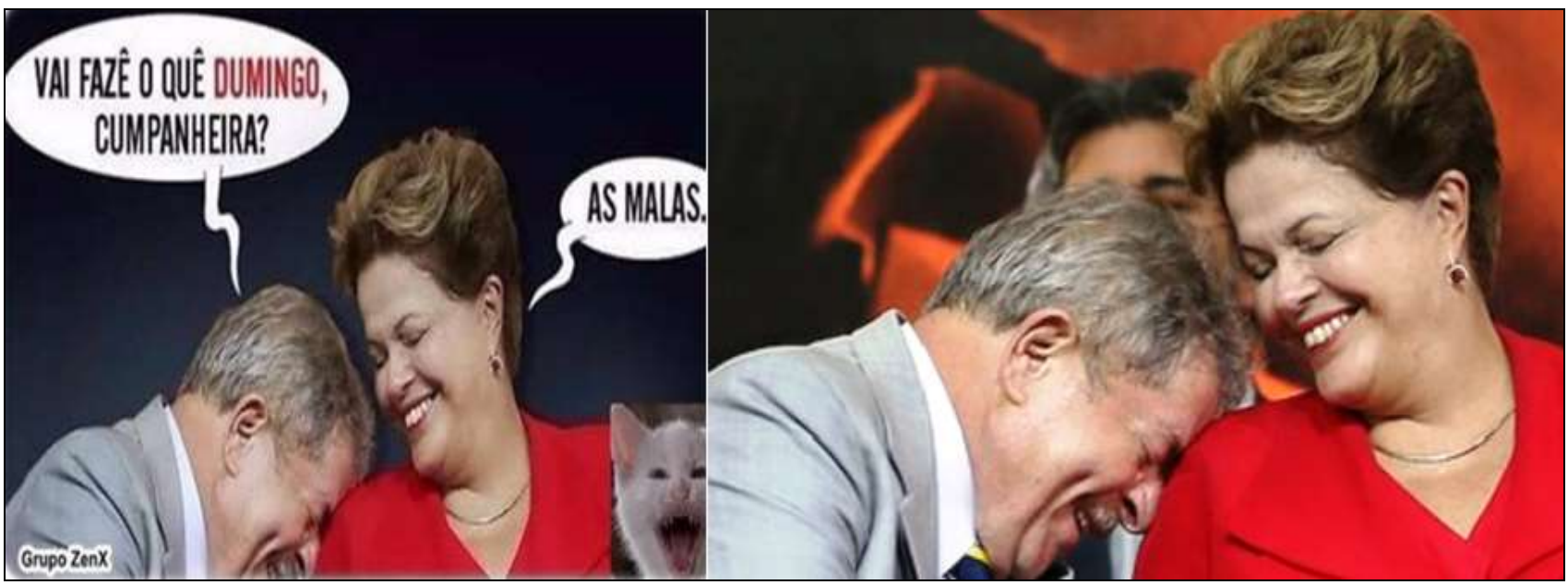

Fonte: Extra (2016)

Fonte: Jornal Ouvidor (2016)

Percebe-se nesse tipo de conteúdo o intuito de disseminação viral para apoiar algum tema político ou candidato. Chagas et al. (2017) fazem uma distinção dos memes políticos em persuasivos, de ação popular e de discussão pública; determinado como 
características dos memes persuasivos a pretensão de convencer o eleitor e ter seu apoio a determinada candidatura, e nesse sentido fazem comparação entre candidatos ou partidos e são conhecidos como estratégicos e mais virais. Os memes de ação popular se caracterizam pela tentativa de mobilizar o cidadão comum com uma construção coletiva de sentido, relacionados à militância partidária. Já os de discussão pública podem tratar de lugares comuns da política, fazendo alusões literária ou culturais ou ainda fazer piadas situacionais e de personagens da política (Chagas et al., 2017). Pode-se identificar nas Figuras 3 e 4 exemplos de memes de ação popular, geralmente criados ou patrocinados por organizações partidárias, empresas ou entidade sindical específica. $\mathrm{Na}$ maioria das vezes a postagem utiliza hashtags para levantar uma bandeira de determinada causa ou o movimento, com slogan de determinada campanha ou com a frase de candidato preferido, utilizados para defender posicionamentos ideológicos e provocar o intelecto do eleitor frente às discussões políticas atuais, disseminando os pontos negativos e positivos dos candidatos (Mian \& Castilho, 2019).

Figuras 3 e 4 - Memes de Ação Popular.

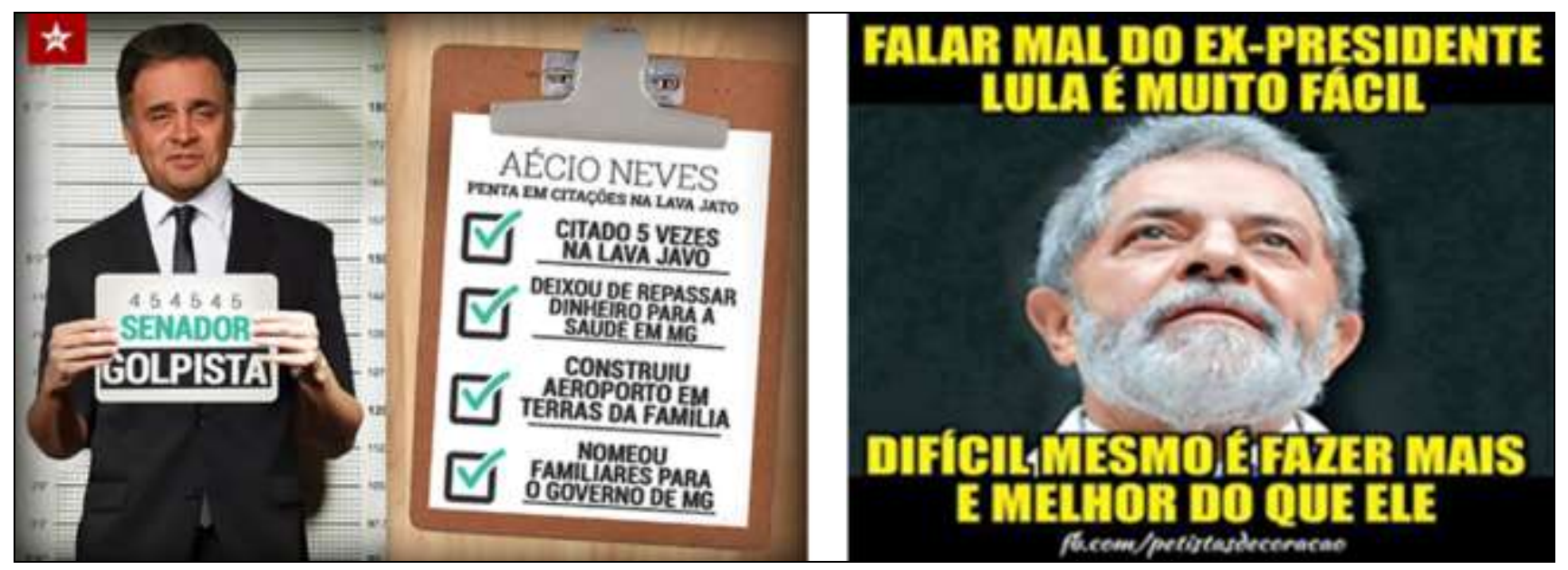

Fonte: Lauretti e Perri (2018)

Fonte: PeTistas de Coração (S.D.)

Chagas et al. (2017) fazem ainda uma separação dos memes de ação popular de acordo com sua dinâmica, categorizandoos como de ação coletiva e redes curadas por organizações, quando o conteúdo é patrocinado por organizações específicas e não pela militância; de ação conectiva híbrida e redes catalisadas por organizações, quando o conteúdo é resultado de ação da militância, mas sem vinculação a organizações partidárias ou qualquer outra entidade; de ação conectiva e redes auto organizadas, quando o conteúdo é de ação coletiva, mas não se constitui como uma organização formal; de ação conectiva e engajamento relativo, quando o conteúdo não está relacionado a um engajamento político em particular, mas resulta de uma tendência ou comportamento.

Os mesmos autores também trazem uma classificação dos memes de discussão pública, dividindo-os em: lugares-comuns da política, como sendo aqueles que apresentam comentários sobre a corrida eleitoral; alusões literárias ou culturais, quando os conteúdos fazem menções a produtos da cultura popular em geral, a gírias da internet, personagens famosos ou celebridades; piadas sobre personagens da política, são os que apresentam conteúdos com comentários sobre personagens específicos da cena política, especialmente os contemporâneos; piadas situacionais, com conteúdo que apresenta comentários sobre reações, expressões faciais, gestuais ou corporais dos candidatos em determinadas situações (Chagas et al., 2017). 
Figuras 5 e 6 - Memes de discussão pública.

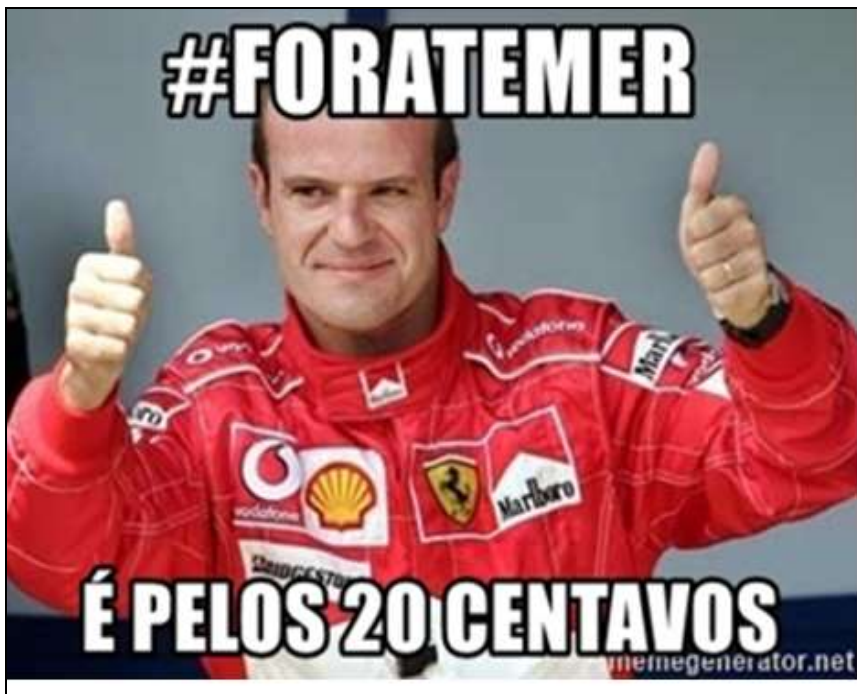

Fonte: Meme Generator (S.D.)

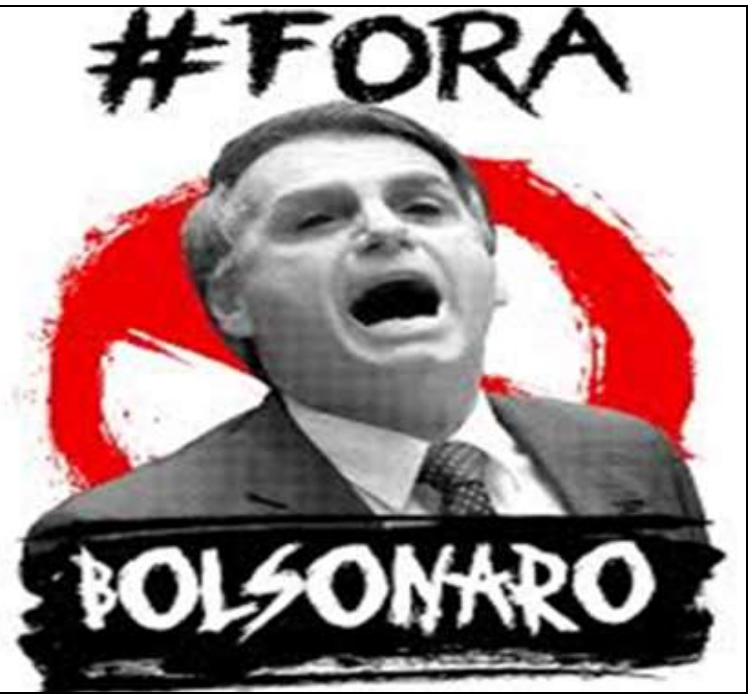

Fonte: Vandal (S.D.).

Vê-se, assim, que a classificação dos memes toma como referência principal os conteúdos e as variáveis relacionadas à política, ao processo de produção de sentido e à finalidade dos internautas ao difundirem os conteúdos. Nesse sentido, é possível depreender que a linguagem memética possui um discurso próprio, dotado de intertextualidades variadas e de um bom repertório cultural. Sua produção e compartilhamento estão associados às práticas nas redes sociais, cumprindo a função de questionar e enfatizar fatos políticos, geralmente em tom humorístico, e espalhá-los rapidamente para o maior número de usuários das redes, alcançando popularidade, mobilização e convencimento dos internautas.

\subsection{Os memes como instrumentos da cultura política e de interação democrática}

Segundo Motta (2009, p. 9) uma conceituação adequada para cultura política seria "conjunto de valores, tradições, práticas e representações políticas, partilhado por determinado grupo humano, que expressa uma identidade coletiva e fornece leituras comuns do passado, assim como fornece inspiração para projetos políticos direcionados ao futuro". Essa forma de conceber a cultura política evoluiu com o avanço da tecnologia e atualmente está relacionada ao ciberespaço e à cibercultura, considerando que os dois termos propostos por Lévy $(1999,2000)$ contempla os fenômenos associados à comunicação no espaço virtual, constituído de linguagem, comportamentos, valores, com fluidez de ideais e representações culturais.

Assim, tudo o que é vinculado ao espaço virtual tem sido objeto de estudo por parte dos pesquisadores, com vistas a entender sua influência, seus impactos e sua colaboração para a cultura atual. Este meio tem sido cada vez mais difundido, tendo em vista ser um novo conceito de comunicação digital que abriga um leque de significados, tanto para os usuários das redes como para cientistas da mídia digital (Sousa et al., 2016).

Os memes são considerados dentro dessa perspectiva de cultura política. Porquanto, como imagens vinculadas às redes, possuem a capacidade de serem utilizados para exprimir opiniões, ideias e comportamentos, com grande poder de mobilização e convencimento. Nesse contexto de representação na cultura política é que surge a possibilidade da linguagem dos memes ser considerada ferramenta capaz de motivar condutas e valores nos debates sociais e de participação política, com probabilidade de transformações na sociedade democrática. 
Research, Society and Development, v. 10, n. 9, e19010917960, 2021

(CC BY 4.0) | ISSN 2525-3409 | DOI: http://dx.doi.org/10.33448/rsd-v10i9.17960

A esse propósito, Mian e Castilho (2019) apontam as redes como um novo espaço público para debate e exposição de ideias, ampliando assim, as vozes dos usuários. Esse posicionamento é referendado por Schneider \& Trevisol (2019) que veem a cultura dos memes como uma forma comunicativa e de interação, com significados e representações ideológicas e discussões no ciberespaço, influenciando comportamentos e dando visibilidade a ideias, valores e condutas e possibilitando relações sociais democráticas. Os autores asseveram que "essa cultura digital impacta e causa transformações relacionadas a democracia, no qual as novas tecnologias permitem que as informações sejam divulgadas e conhecidas não apenas por veículos institucionalizados, mas por redes sociais que passam a compor o espaço público de debate" (Schneider \& Trevisol, 2019, p. 7).

As representações ideológicas citadas por Schneider \& Trevisol (2019), vão ao encontro do pensamento de Nolasco et al. (2020), que acreditam que o meme está inserido em um processo de democratização participativa popular e que a internet é a mídia utilizada para exprimir as opiniões, sendo autônoma produção de informações. Sousa et al. (2016) concordam com esse posicionamento quando dispõem que a sociedade em rede é cada vez mais um lugar de produção de conteúdo e não apenas de recepção.

Nesse sentido, não apenas o espaço comunicacional está mudando, mas a sociedade está se reinventando dentro desse novo espaço, e perceber o meme na sua concepção comunicativa e de interação no ciberespaço, com poder de influenciar comportamentos e dar visibilidade a ideias, valores e condutas, eleva as dimensões de sua compreensão sociocultural dentro do contexto de ciberdemocracia. E assim, a linguagem memética pode ser entendida como ferramenta potencialmente capaz de instigar e viabilizar a participação do cidadão no sistema político e causar transformações na sociedade democrática. Assim não sendo, corre-se o risco de enfraquecimento de sua construção de interação política e de representatividade democrática.

\section{Resultados e Discussão}

Com base nas análises das pesquisas científicas feitas através dos parâmetros estabelecidos na metodologia escolhida, foi possível destacar 4 pontos relevantes de discussão acerca dos memes e a tecnologia, sendo eles:

\section{O avanço das tecnologias e o seu uso aproximaria ou não o meme político como proposta democrática?}

Nolasco et al. (2020) acreditam que o meme político faz parte de uma cultura participativa e seu uso motiva o cidadão a um papel ativo inserido na sociedade; e que, de acordo com Popolin (2019) potencializa o debate público democrático. Para Carvalho et al. (2017) essa cultura participativa indica uma tendência no comportamento político em ambiente digital, uma vez que esse espaço, usado para se relacionar com outros indivíduos, é muito heterogêneo, reunindo públicos muito distintos, principalmente com visões político-ideológicas opostas ou, pelo menos, distintas.

No entendimento de Schneider e Trevisol (2019) o novo conceito de cultura política, que permitiu que as informações fossem divulgadas e conhecidas não apenas por veículos institucionalizados, mas também por redes sociais, efetivaram mudanças consideráveis no espaço público de debate, impactando diretamente na democracia.

Nesse viés, Junior (2020) observou que o papel democrático que os memes políticos exercem nas manifestações populares faz com que surja um sentimento de insatisfação por parte dos cidadãos, e que na maioria das vezes, reflete nitidamente nos resultados das eleições, podendo ser interpretados como uma tentativa de mudança do sistema político. Essa exposição na internet, porém, no entendimento de Sousa et al. (2016) e Azevedo (2017) pode mudar as características de comunicação em rede, e sobretudo, efetivar mudanças na forma de ver as eleições, levando as redes sociais a comporem um espaço público de debate e participação na discussão pública de uma forma mais leve, visto o caráter de humor desse espaço. 
Research, Society and Development, v. 10, n. 9, e19010917960, 2021

(CC BY 4.0) | ISSN 2525-3409 | DOI: http://dx.doi.org/10.33448/rsd-v10i9.17960

Noutro entendimento, há autores que consideram o meme político um enfraquecedor da democracia representativa, mediante a individualização causada ao usuário, além de dar ao internauta a sensação de distanciamento e falta de compromisso com a política, incentivando as posições radicais e fragilizando a diversidade de opiniões nas redes (Chagas, 2018). Esse entendimento é compartilhado por Rezende e Farias (2018), considerando que, dado o seu potencial comunicativo, os memes políticos podem ser usados como novas estratégias pelos candidatos para coagir a opinião pública e atender a interesses ilegítimos.

Nessa perspectiva, percebe-se que o avanço tecnológico e o contexto de comunicação política do meme na sociedade informacional fortalece a sua representatividade democrática, mesmo que para alguns autores essa possibilidade seja menos animadora; já que entendem que munidos de forte dose de informação propagandística, que se usada no interesse ilegítimo, tais conteúdos podem coagir a opinião pública e arrefecer seu potencial democrático.

\section{Qual o papel do meme político no universo da Cibercultura?}

"Os memes estão no rol de elementos tipicamente emergidos da cibercultura, que dão voz aos indivíduos e evidenciam uma importante forma de apropriação das redes" (Mian et al., 2019, p. 18). Ainda, de acordo com Schneider e Trevisol (2019), esse espaço torna-se um terreno fértil para a perpetuação e compreensão dos memes como construções culturais, entendidos como formas ideológicas de representações do mundo real sendo manifestado no espaço virtual. Chagas et al. (2017, p. 7) tem esse mesmo entendimento ao enxergar o meme "como produto cultural, que depende de um repertório cultural extraído de relações sociais, memórias, referências históricas, geográficas, econômicas e de aspectos conjunturais específicos".

Essas relações que acontecem no ciberespaço são entendidas, segundo Barros e Milanezi (2020), como uma interação simbólica de disputas ideológicas e/ou políticas, causando ao cibernauta uma sensação de exercício do dever cívico, que talvez não poderia ser expressado em ambientes convencionais. Esse entendimento, de acordo com Chagas et al. (2017), torna as redes um espaço de representatividade muito além do entretenimento e de lugar comum, e ratifica-o como lugar de criação e compartilhamento democrático, capaz de ampliar a liberdade de expressão.

Assim, na sociedade intelectualizada e informatizada, o meme emerge como fator preponderante para a comunicação política e ferramenta de reprodução e recepção de ideias e valores, com potencial de gerar novos modos de agir e de interação social, e nesse sentido, um lugar propício para construções culturais no universo da cibercultura.

\section{Qual o impacto dos memes político para a representatividade nas eleições?}

Tay (2020), Rentschler et al. (2020) consideram o destaque dado ao meme nas redes sociais e sua representatividade nas eleições como uma grande ferramenta para o marketing político, digital e expressão popular, observando que essa nova modalidade participativa mistura política, idealismo, lutas de classes no novo discurso contemporâneo. Os autores percebem a visibilidade dada aos memes como importante nesse contexto, uma vez que acessível aos cidadãos acaba por contribuir para exposição de assuntos como corrupção, vida pregressa e atos da vida cotidiana dos políticos, que poderiam passar despercebidos, colaborando para o questionamento dessas situações.

Schneider e Trevisol (2019, p. 12) complementam que os memes "desempenham importante papel no que concerne a fomentar discussões e levar a reflexão a ambientes virtuais, pois como nos alerta Lévy as comunidades virtuais procuram novas formas de opinião pública, sendo considerados como uma ótima forma de indicadores eleitorais, pois eles impulsionam e determinam a opinião pública a respeito de um dado candidato, partido ou uma proposta específica". Azevedo (2017) e Popolin (2019) corroboram com esse entendimento quando asseveram que, na realidade atual, o cidadão conectado está mais interessado 
em manifestar seus valores pessoais e suas discordâncias em questões políticas nas redes sociais em detrimento dos tradicionais discursos partidários, e assim recorrem à internet para manifestar opiniões e preferências políticas, que muitas vezes são realizadas por meio dos memes.

Outro ponto a ser destacado diz respeito à repercussão do meme e o seu poder de influência na competição eleitoral, o que o tem levado políticos a mudar estratégias e fazer uso de técnicas publicitárias e de marketing, empregando "técnicas de sondagem, monitoramento e pesquisa de opinião para acompanhar as flutuações do eleitorado e evocar um efeito de interação direta em favor de sua agenda estratégica de campanha, o cidadão comum tem se ocupado menos com a expressão do discurso público e mais com a manifestação de discordâncias e valores morais pessoais" (Chagas et al., 2017, p. 5).

No Brasil, observou-se essa mudança nas eleições a partir de 2014, e que segundo Chagas et al. (2017), foi o marco de veiculação do material meme nas mídias sociais, deixando marcas no imaginário jornalístico como as "eleições dos memes", com vasto material de piadas eleitorais sendo repassado e transmitido por diversos veículos de comunicação on-line e off-line, com intensa repercussão. Para candidatos, porém, as eleições de 2014 foi o marco para "desenvolver estratégias de influência para a web, desde conteúdos criados especificamente para Twitter ou Facebook, a robôs que, supostamente, ampliariam o alcance de suas mensagens reproduzindo-as sub-repticiamente por meio de contas falsas" (Chagas et al., 2017, p. 1).

Nesse contexto, a linguagem memética tem forte poder de influência nas disputas eleitorais, com representatividade que não pode ser ignorada pelo espaço de debate público e pelas estratégias políticas, visto ser um veículo considerável de divulgação de ideias e opiniões e fomento de discussões capaz de provocar transformações na opinião pública.

\section{Quais as atuais formas de classificações metodológicas?}

Nesse estudo tomou-se por base o conceito cunhado por Richard Dawkins em 1976, que é seguido pela maioria dos autores pesquisados. Sua origem faz referência a informações disseminadas de maneira proliferada, fazendo um comparativo com o gene humano e sua capacidade de se replicar (Moreira, 2017; Chagas et al., 2017; Popolin 2019; Mian \& Castilho, 2019). Posteriormente Chagas (2018) organizou uma classificação metodológica própria, desenvolvida a partir dos estudos de Richard Dawkins (1976) e de outros autores internacionais, com uma análise taxonômica em que é possível fazer a categorização dos memes em persuasivos, ação popular e de discussão pública, conforme estudado no tópico 3.2.

Davison (2020) considera outra maneira de classificar os memes, onde se observa primeiramente os componentes da peça de mídia (meme), para depois classificá-la; sendo necessário observar sua manifestação, seu comportamento e o seu tipo ideal. Dessa forma, a manifestação seria o conjunto de objetos criados pelo meme e os registros de sua existência, observando o arranjo de partículas físicas do tempo e espaço; já o comportamento é a ação tomada por um indivíduo a serviço do meme, que automaticamente cria o procedimento comportamental; e o tipo ideal é a carga ideológica que é passada adiante, constituindo-se na soma das suas anteriores; e assim sendo, o ideal determina o comportamento, que cria a manifestação.

De acordo com as pesquisas feitas até a data determinada na metodologia, as classificações existentes para o meme são as relatadas neste artigo; o que sugere uma lacuna existente nos campos metodológicos de análise.

\section{Considerações Finais}

Com as inovações tecnológicas ampliaram-se as possibilidades e o fluxo de informações no espaço virtual, fazendo emergir a interface entre o fazer político e o fazer comunicacional, impondo à democracia digital novos parâmetros para lidar com as complexidades surgidas na relação entre as tecnologias e as práticas democráticas. 
Nesse cenário emerge o meme, alterando a forma de produzir e consumir conteúdo no espaço virtual, influenciando comportamentos e relações sociais, replicando ideias e opiniões, provocando a opinião pública e suscitando transformações no mover da política.

É nessa perspectiva que os memes políticos são percebidos e analisados nas pesquisadas acadêmicas, tomados em seu significado de interação social, comunicação política e construção cultural. E todo esse potencial comunicativo e de interação é que pautam as discussões dentro da perspectiva de cultura política e de representatividade democrática, para, assim, conceber a linguagem memética na sua dimensão de transformação e de interação dentro da cibercultura.

Tem-se, assim, que a capacidade de comunicação e divulgação de ideias e opiniões dos memes consolida a sua expressividade no debate público e fortalece a sua representatividade democrática. Mas há que se considerar as complexidades desse cenário na realidade brasileira, onde ainda se debate a legitimidade e transparência das ferramentas digitais e do sistema político e se vivencia atuação de internautas com posições radicais, que desrespeitam a diversidade de opiniões e não se pautam por valores éticos e morais ao se manifestarem; o que enfraquece e relativiza o potencial democrático e de interação sociocultural da linguagem memética.

Apesar da diversidade de pesquisas acadêmicas sobre a temática, observou-se uma carência de embasamento teórico acerca das metodologias de análise e classificação dos memes e a necessidade de investigação mais profunda dos pesquisadores na percepção da linguagem memética como formadora de opinião pública. Assim, considerando a importância do debate na academia, sugere para trabalhos futuros estudos atualizados sobre a classificação dos memes e debates mais consistentes acerca da cultura memética como formadora de opinião pública e sua influência nos rumos da sociedade da informação, no intuito de nortear pesquisadores e na expectativa que possibilitem novos e instigantes resultados.

\section{Referências}

Azevedo, C. F. (2017). Discussão Pública sobre Política na Internet com Memes: uso do humor pelo cidadão conectado ludovicense para se aproximar do universo da política. IV Jornada de Pesquisa e Extensão em Comunicação. https://www.jopecom.ufma.br/anais_2017.pdf\#page=140

Barbosa, J. S., Borges, D., de Oliveira, D. C., de Jesus, D. C., \& de Miranda, W. F. (2021). A proteção de dados e segurança da informação na pandemia COVID19: contexto nacional. Research, Society and Development, 10(2). 10.33448/rsd-v10i2.12557

Barros, L. M., \& Milanezi, M. J. F. (2020). Disputas simbólicas em memes das eleições presidenciais brasileiras em 2018. Lumina, 14(1), 174-191. 10.34019/19814070.2020.v14.29629

Botelho, J. M., \& Cruz, V. A. G. da (2013). Metodologia Científica. Person Education do Brasil.

Brasil. (1988). Constituição da República Federativa do Brasil de 1988. [Coleção Saraiva de Legislação]. (21a ed.). Saraiva.

Bucci, E. (2019). Existe democracia sem verdade factual? Estação das Letras e Cores.

Carvalho, F. C., Massuchin, M. G., \& Mitozo, I. B. (2017). Eleições e debate político on-line em 2014: os comentários no Facebook do jornal O Estado de S. Paulo. Revista Brasileira de Ciência Política, (23), 295-320. 10.1590/0103-335220172309

Castells, M. (1999). A sociedade em rede. A era da Informação: economia, sociedade e cultura. Paz e Terra.

Castells, M. (2003). A galáxia da internet: reflexões sobre a internet, os negócios e a sociedade. Jorge Zahar.

Chagas, V., Freire, F. A., Rios, D., \& Magalhães, D. (2017). A política dos memes e os memes da política: proposta metodológica de análise de conteúdo de memes dos debates eleitorais de 2014. Intexto, (38), 173-196. 10.19132/1807-8583201738.173-196

Chagas. V. (2018). A febre dos memes de política. Revista Famecos, 25(1), 1-26. 10.15448/1980-3729.2018.1.27025

Cristóvam, J. S., Saikali, L. B., \& Sousa, T. P. (2020). Governo Digital na Implementação de Serviços Públicos para a Concretização de Direitos Sociais no Brasil. Sequência, 41(84), 209-242. 10.5007/2177-7055.2020v43n84p209

Davison, P. (2020). A linguagem dos memes de internet: dez anos depois. In Chagas, V. (org.) A cultura dos memes: aspectos sociológicos e dimensões políticas de 
Research, Society and Development, v. 10, n. 9, e19010917960, 2021

(CC BY 4.0) | ISSN 2525-3409 | DOI: http://dx.doi.org/10.33448/rsd-v10i9.17960

um fenômeno do mundo digital (pp. 139-155). Edufba.

Dueñas, P. P. M., González, E. S., \& Moreno, A. B. (2019). Uso e influencia de Twitter en la comunicación política: el caso del Partido Popular y Podemos en las elecciones generales de 2016. Cuadernos, (45). 10.7764/cdi.45.1595

Extra. (2016). Memes a favor do impeachment de Dilma invadem as redes sociais. https://extra.globo.com/noticias/brasil/memes-favor-do-impeachment-de-dilmainvadem-as-redes-sociais-19106216.html

Gil, A. C. (2002). Como elaborar projetos de pesquisa, Atlas.

G1. (2014). Confira memes da campanha a presidente na eleição 2014. http://g1.globo.com/politica/eleicoes/2014/noticia/2014/10/confira-memes-da-campanhapresidente-na-eleicao-2014.html

Hypeness. (2017). Paulistanos podem ajudar o seu Madruga a não ser expulso da Vila do Chaves. https://www.hypeness.com.br/2017/06/paulistanos-podem-ajudaro-seu-madruga-a-nao-ser-expulso-da-vila-do-chaves/

Jornal Ouvidor. (2016). Lula será Ministro da Casa Civil. http://jornalouvidor.com.br/noticia/lula-sera-ministro-da-casa-civil-/7457

Junior, W. N. B. (2020). Expansão democrática pelas redes sociais: uma visão das eleições de 2018. Brazilian Journal of Development, 6(7), 44889-44903. $10.34117 /$ bjdv6n7-201

Lauretti, P., \& Perri, A. (2018). Memes democratizaram a política, diz pesquisador. https://www.unicamp.br/unicamp/ju/noticias/2018/05/23/memesdemocratizaram-politica-diz-pesquisador

Lévy, P. (1999). Cibercultura. São Paulo: Editora 34 Ltda.

Lévy, P. (2000). O Ciberespaço como um Passo Metaevolutivo. Revista Famecos, 7(13), 59-67. 10.15448/1980-3729.2000.13.3081

Magrani, E. (2014). Democracia conectada: a internet como ferramenta de engajamento político-democrático. Juruá.

Meme Generator. (2013). https://memegenerator.net/Rubinho-Barrichello

Mian, M. B., \& Castilho, A. (2019). Ciberativismo potencializado via memes: uma análise de articulação de pautas políticas e sociais nas redes. Aurora: Revista de Arte, Mídia e Política, 12(34), 110-128. 10.23925/2019.v34.artigo1

Moreira, T. L. (2017). A construção da narrativa política através dos memes: o caso Temer x Joesley e a repercussão na Internet. $40^{\circ}$ Congresso Brasileiro de Ciências da Comunicação.

Motta, R. P. S. (2009). Desafios e possibilidades na apropriação de cultura política pela historiografia. In Motta, R. P. S. (org.), Culturas políticas na História: Novos Estudos (pp. 13- 37). Belo Horizonte: Argvmentvm.

Neves, J. L. (1996). Pesquisa qualitativa: características, usos e possibilidades. Caderno de Pesquisas em Administração, 1(3), 1-5. https://www.hugoribeiro.com.br/biblioteca-digital/NEVES-Pesquisa_Qualitativa.pdf

Nolasco, A., Ávila, L. F., \& Jungblut, A. L. (2020). Likes, memes e militância: ciberativismo na internet brasileira. Conversas \& Controvérsias, 7(1), 1-14. $10.15448 / 2178-5694.2020 .1 .35328$

Oliveira, R. S., Cruz, R. L. S., \& Silva, F. S. R. (2019). Caça às bruxas às fake news: os possíveis desdobramentos da criminalização das "notícias falsas". In Polido et al. Políticas, Internet e Sociedade (pp. 113-119). Iris.

PeTistas de Coração. (S.D.). https://www.facebook.com/pg/petistasdecoracao/photos/

Pinho, J. A. G. de (org.). (2012). Estado, sociedade e interações digitais: expectativas democráticas. Edufba.

Popolin, G. (2019). Memes de discussão pública: o mito da conspiração comunista no Brasil. http://ctpol.unb.br/compolitica2019/GT4/gt4_Popolin.pdf.

Prodanov, C. C., \& Freitas, E. C. (2013). Metodologia do Trabalho Científico: Métodos e Técnicas da Pesquisa e do Trabalho Acadêmico. Rio Grande do Sul. Feevale.

Rentschler, C. A; Thrift, S. C., \& Chagas, V. (org.). (2020). Praticando feminismo na rede: o riso em rede e o meme "Binders Full of Women". Salvador: Edufba.

Rezende, H. P., \& Farias, L. A. (2018). A influência Anárquica e violenta dos memes na política brasileira. Revista Observatório, 4(1), 730-750. 10.20873/uft.2447$4266.2018 \mathrm{v} 4 \mathrm{n} 1 \mathrm{p} 730$

Rocha, P. C., Jucá, S. C. S., \& da Silva, S. A. (2019). A evolução das Tecnologias da Informação e Comunicação na perspectiva de Touraine, Bell e Castells. Research, Society And Development, 8(5), 01-12. 10.33448/rsd-v8i5.928

Rodríguez-Andrés, R. (2018). Trump 2016: ¿presidente gracias a las redes sociales? Palavra Clave, 21(3), 831-859. 10.5294/pacla.2018.21.3.8

Schneider, A. G., \& Trevisol, M. G. (2019). Uma reflexão sobre redes sociais e memes como forma interativa. XXI Congresso de Ciências da Comunicação na 
Research, Society and Development, v. 10, n. 9, e19010917960, 2021

(CC BY 4.0) | ISSN 2525-3409 | DOI: http://dx.doi.org/10.33448/rsd-v10i9.17960

Região Sudeste. https://portalperiodicos.unoesc.edu.br/aecs/article/download/23768/14048\#page=7

Shifman, L. \& Chagas, V. (org.). (2020). Uma biografia telegráfica de um encrenqueiro conceitual. Edufba.

Silva, S. P., Bragatto, R. C. \& Sampaio, R. C. (org.) (2016). Democracia digital, comunicação política e redes: teoria e prática. Folio Digital.

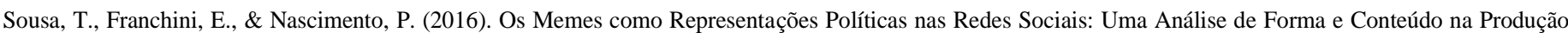

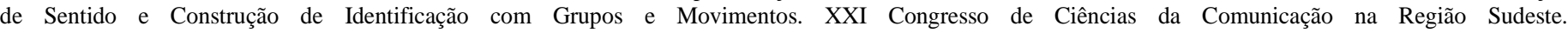
https://www.portalintercom.org.br/anais/sudeste2016/resumos/R53-0885-1.pdf

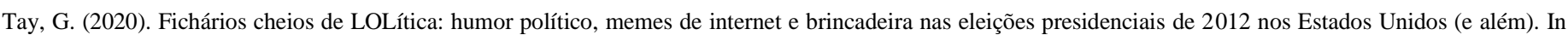
Chagas, V. (org). A cultura dos memes: aspectos sociológicos e dimensões políticas de um fenômeno do mundo digital (pp. 281-322). Salvador: Edufba.

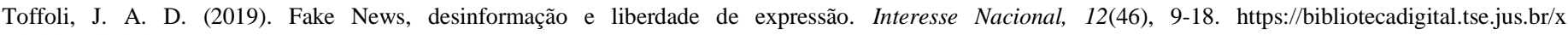
mlui/handle/bdtse/7624

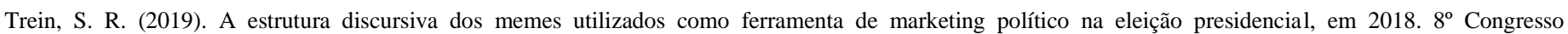
Compolítica. http://compolitica.org/novo/anais/2019_gt9_Trein.pdf

Vandal. (S.D.). https://www.vandal.com.br/camisetas/estampa-forabolsonarosemalma 